https://doi.org/10.18485/iipe_60nam.2021.ch6

\title{
THE SOVIET UNION AND THE NON-ALIGNED MOVEMENT
}

\author{
Ruslan VASILIEVICH KOSTIUK ${ }^{1}$ \\ Ekaterina PETROVNA KATKOVA²
}

\begin{abstract}
The chapter is devoted to the evolution of relations between the USSR (Russian Federation) and the Non-Aligned Movement (NAM). The authors show that the ideology and context of the Cold War, as well as the anti-imperialist and anti-neocolonial strategies and rhetoric of most nonaligned countries, played an important role in determining the Soviet Union attitude towards the NAM. From 1961, Soviet diplomacy considered the $N A M$ an ally on the world stage and a friendly international organisation. A high level of relations along the USSR-NAM line was also maintained thanks to the friendly relations between the Soviet Union and the countries that were the Movement leaders. The authors emphasize that the Soviet Union played a decisive role in defining the strategy of the entire "world socialist system" in relation to the non-aligned countries. The approaches and assessments of Moscow and the NAM regarding most world's political problems and "hot conflicts" on the planet were similar until the collapse of the USSR. The chapter also shows the two sides positions similarities regarding the need for international economic order democratization. During the "perestroika" period in the USSR, relations with the NAM reached an even higher-quality level. After the USSR's collapse, the NAM was practically "forgotten" in Russian foreign policy. However, in recent
\end{abstract}

\footnotetext{
${ }^{1}$ Professor of the International Relations Theory and History Department, St. Petersburg State University, St. Petersburg, Russia.

E-mail: rouslan_k@mail.ru

${ }^{2}$ Assistant of the History of Culture, State and Law Department, St. Petersburg Electrotechnical University "LETI", St. Petersburg, Russia.

E-mail: ekaterinak.17@gmail.com
} 
years the Russian Federation has become very active in developing relations with the non-aligned states.

Key words: Soviet Union, Non-Aligned Movement, foreign policy, international relations, Communist Party of Soviet Union, similarities, positions.

\section{Introduction}

The Non-Aligned Movement (NAM) turned 60 years old in 2021. The historical paradox is that exactly half of this period (before 1991) is associated with Soviet policy towards this Movement, while the other half falls in the Russian period. However, we believe that from a geopolitical point of view, these two halves are not equal. Taking into account the role that the Soviet Union played in the international relations system during the Cold War era, it seems to us that the first period was more important and rich in historical events. It is not surprising that in the late Soviet decades, especially in the 1980s, a large number of academic works were published in the USSR on the subject, including monographs (in particular, The Non-Aligned Movement (1985), The Non-Aligned Movement in the Modern World (1985), World socialism and the Non-Aligned Movement (1988), Utegenova D. K. The UN and the Non-Aligned Movement (1991)), while in the postSoviet period, at best, articles appeared on certain aspects of the NAM's activities. Even before the NAM creation, Moscow began to pay significant attention to the developing countries problem. The Soviet Union in the international arena actively advocated the elimination of all colonialism and dependence forms, which strengthened its authority in the liberated countries. On the other hand, during the 1950s, Soviet diplomacy was quite loyal to the development of integration processes among non-aligned countries, supporting, in particular, the ideas of the Bandung Conference. The fact is that from the very beginning of the NAM functioning, the Soviet leaders viewed the Movement as a privileged partner. Welcoming the First Conference of Non-Aligned Countries in Belgrade in 1961, Moscow expressed support for the goals of the new Movement: "We know that the peoples of the countries of Asia, Africa and Latin America who have awakened and straightened their mighty shoulders, who were previously in the chains of colonial bondage, together with other peoples raise their voice in favour of peace, national independence and freedom." (NonAligned Movement, 1979, p. 52). It was especially important for Moscow's communist foreign policy that NAM "originated in the atmosphere of the struggle against colonialism" (World Socialism and the Non-Aligned 
Movement, 1988, p. 7). It should be pointed out here that the important role of NAM in world politics, in the system of international relations was emphasized by the Soviet leaders throughout the 1960-1980s. Obviously, during the Cold War, especially during the years of its aggravation, it was extremely important for Soviet diplomacy to have, if not support, then a minimum of loyalty to the developing countries, which constituted the vast majority of all states on the planet and the clear majority of members in the United Nations Organisation (UN). In this regard, the Soviet leadership in relation to NAM discourse has always been emphatically friendly and respectful. The USSR leaders argued that "since the Soviet Union always opposes political blocs and military alliances and is an active supporter of the peaceful coexistence of states with different social systems, the refusal of the liberated countries to join both military-political alliances does not mean that they are hostile to the USSR and other socialist countries." (NonAligned Movement, 1985, p. 5). At the same time, the USSR's leaders and the Communist Party of the Soviet Union (CPSU) each time "stressed the existence of objective political conditions for maintaining solidarity with the countries that made up the NAM: for the practical implementation of nonaligned processes" (The Non-Aligned Movement in the Modern World, 1985 , p. 3). Holistically and globally, the Soviet foreign policy proceeded from the fact that the specific historical conditions of the Non-Aligned Movement can be viewed as an important ally of Moscow and the entire "world socialist system", not only due to the fact that most of the Movement's member countries belong to the postcolonial world but also due to political and ideological factors. Thus, in the Report of the Central Committee of the CPSU at the XXVI Congress (1981), it was noted that the strength of the NAM consists "in the direction against imperialism and colonialism, against war and aggression. We are confident that the key to further enhancing the role of the non-aligned movement in world politics which we would welcome - is in its loyalty to these fundamental principles." (Materials of the XXVI Congress of the CPSU, 1981, p. 15). In fact, after the end of World War II, that is, even before the creation of the NAM, the communist leadership of the USSR made a bet on a frontal confrontation with the capitalist West in the struggle for influence in the postcolonial world. This stake implied support for revolutionary and anti-imperialist forces in the Third World. But if in the late Stalinist period this meant tactics primarily to support local communist and Marxist-Leninist parties, then, starting from the mid-1950s, Moscow's position on internal processes in developing countries has become more flexible, allowing interaction with various areas of "progressive" forces. From the point of view of the Soviet 
leaders, "the non-aligned movement ... maintains unity with a significant expansion of its ranks, proving its stability as an interstate formation of developing countries and, on the whole, has confirmed its anti-imperialist, democratic, anti-militarist character." (The Non-Aligned Movement in the Modern World, 1985, p. 18). This point of view was cultivated by Soviet propaganda during the first quarter of a century of the Movement existence when it was important for the Soviet leadership to obtain solidarity from the NAM, or at least most of its members, on certain world politics problems and conflicts, in which the positions of the USSR fiercely clashed with the United States of America (USA) or Western European countries. Later, in the Gorbachev's period, Soviet researchers pointed out that "the fundamental ideas of non-alignment provide the widest opportunities for the movement to effectively implement the new order of peace laid down by its founders - from creating a moral climate of intolerance to violence to promoting and implementing practical measures to the creation of a "new world order."' (Dmitrieva, 1990, p. 39). Of course, Moscow was interested in changing the balance of forces within the NAM in favour of the socialist camp. But even American experts admitted, speaking of the NAM, that "... this is an independent trend, and not the result of long-term growth or Moscow's diplomatic initiatives." The interests of the Soviet Union and the interests of the Non-Aligned Movement basically coincided with the challenges of the post-war international order established by the United States and the rest of the West (Jackson, 1983, p. 19).

\section{The Non-Aligned Movement remains an important factor in international relations}

Both for the Soviet foreign policy ideological doctrine and in terms of its practical implementation, the role of the postcolonial and non-aligned countries in the 1960s-1980s was very significant and principled. The documents of the CPSU congresses invariably emphasized that "the nonaligned movement was and remains an important factor in international relations" (Materials of the XXVI Congress of the CPSU, p. 15). Soviet leaders constantly emphasized the progressivism of NAM and its uniqueness in the world political arena. It is important to note that Soviet leaders themselves regularly talked about the existence of a "common foundation" or proximity of Moscow and the NAM positions. This is especially characteristic of those years when the Movement was headed by countries that were active partners and even allies of the Soviet Union on the international stage. Throughout the 1960s-1980s, those were Yugoslavia, Egypt, Algeria, Cuba, 
India, Zimbabwe, that is, more than half of all the presidency countries that came during the Cold War. All of these countries were separate varieties of the left, including Marxist, political regimes. Of course, this circumstance contributed to the USSR's foreign policy cooperation not only with them, but also with the NAM. But, of course, not only purely ideological and political closeness determined the nature of Moscow's interaction with the Movement. In particular, the leaders of the USSR regularly said that "the coincidence of positions or proximity, both in the general assessment of situations that pose a threat to peace and international security, and in the approach to the ways and methods of resolving specific conflicts, is an objective basis for active interaction between world socialism and the NonAligned Movement. Implementation of efforts is aimed at the peaceful settlement of conflict situations." (World Socialism and the Non-Aligned Movement, 1988, p. 64). The Soviet media covered the NAM summits every time, while the materials of congresses and other events of the CPSU invariably noted the high and positive role of the Movement in the international relations system, and the NAM itself was "systemically" assessed as positive and friendly to the Soviet Union and the "world socialist system" subject. For example, it can be noted that the Political Declaration adopted at the Delhi NAM Conference in 1983 was assessed very positively in the USSR, since it showed that "the quintessence of the non-alignment policy is the struggle against imperialism, colonialism, neocolonialism, apartheid, racism, including Zionism, and against all forms of foreign aggression, occupation, domination, interference, hegemony, as well as against the great-power politics of blocs." (Non-Aligned Movement, 1985, p. 7). It should be pointed out here that at the official level in the USSR, they have always denied accusations of "hegemony" coming from China or Western capitalist countries; just as the Soviet Union did not recognize that it had any "great-power politics". Of course, in the Soviet Union, they were fully aware that among the member countries of the Non-Aligned Movement there are a wide variety of states whose political and socioeconomic system is very far from the ideas of "scientific socialism" and is neocolonial, primitive capitalist, if not semi-feudal in nature. However, "globally" this circumstance did not bother either the leaders of the USSR or those Soviet scientists and researchers who were specifically dealing with the problems of developing and non-aligned states. In the collective monograph "Non-Aligned Movement" (1985), the following thesis was affirmed on this score: "Despite all the socio-economic diversity of the countries participating in the Non-Aligned Movement, they all share the similarities of historical destinies, an unequal position in the world economy, 
the incomplete struggle for economic independence, the desire to escape from age-old poverty and backwardness. This creates a fairly stable basis for uniting their efforts in the struggle against imperialism, colonialism, racism and apartheid, increasing their role in world affairs." (Non-Aligned Movement, 1985, p. 5-6). Accordingly, the foreign policy strategy of the Soviet leadership proceeded not only from the thesis about the presence of common elements of the world political vision between the socialist camp and the non-aligned countries, but also from the understanding that between the imperialism of the US and their Western European allies and the aspirations of the countries that joined the NAM, there is a deep divide and antagonism. At the same time, Soviet ideologists always emphasized that alone, without the USSR's and its allied states' support and solidarity, the non-aligned countries would not be able to achieve their goals of democratizing international political and economic relations. Until its collapse, the USSR continued to be an "ideological" state, the centre (though no longer indisputable) of the international communist and revolutionary movement. The foreign policy aspirations and motives of the CPSU leadership - taking into account the dynamics of world politics and geopolitical realities - largely obeyed ideological postulates and principles. From this point of view, it is fair to conclude that the foreign policy of the USSR during this period continued to be essentially leftist, anti-capitalist, anti-imperialist and internationalist. If we take into account this moment, then the principled attitude of Moscow towards the non-aligned countries and also towards the NAM becomes clearer. This attitude cannot be perceived through the prism of a mercantile, "market" foreign economic and trade dimension. By the end of the USSR's existence, one could conclude that this was the weakness of the Soviet international strategy. However, during the period of the USSR's power as one of the two superpowers, such a line of behaviour contributed to the growth of the international prestige of the Soviet state and the strengthening of its position just among the nonaligned countries. For the Soviet and communist foreign policy discourse, the belonging of one or another international or political force to the antiimperialist camp already made this force at least a potential USSR's ally. From the Soviet communist's point of view, "Non-Aligned Movement...is the main anti-imperialist association of developing countries, advocating national liberation at the intergovernmental, interstate level on a global scale. The emergence, development and strengthening of such an international association became possible only under the conditions of a new, changed in favour of socialism, the balance of power in the world arena..." (NonAligned Movement, 1985, p. 378). In fact, the very principles that the NAM 
shared from its very inception (anti-imperialism, anti-colonialism, rejection of apartheid, racism, etc.) were fully applicable to the content of the Soviet foreign policy. For the CPSU's ideology, the appeal of the NAM, which had been repeated many times since the first declaration of the countries participating in the Movement, on the need to abolish colonialism, neocolonialism and imperialism in all its forms, was perfectly suited. Of course, the interpretation of these enemies of "progressive humanity" by the international communist movement and most of the non-aligned states was not identical. However, the very principled rejection of imperialism in all its manifestations, in fact, brought the Soviet Union and the NAM closer together. As international relations evolved and the ranks of the NonAligned Movement expanded, the very perception of imperialism within its ranks became more "flexible"; in the NAM documents, concepts and interpretations of "economic imperialism", "information imperialism", and "cultural imperialism" appeared. All of this was welcomed in the Soviet Union and interpreted as examples of the NAM's involvement in the broad international anti-imperialist movement. Since the NAM from the very first years of its existence actively supported the national liberation movement, this factor also brought the Movement closer to Moscow; as you know, the very foreign policy strategy of the Soviet state, even at its debut stage, was distinguished by tough anti-colonialism and full support for the national liberation movement in Asia and Africa. After 1945, the USSR played an extremely important role in the UN in advancing the peoples of dependent countries to full-state independence. During the period from the 1960s to the 1980s, if we take a variety of historical examples (the anti-colonial struggle of the Portuguese colonies in Africa, the situation in South Africa, the Palestinian question, etc.), the positions taken by Soviet diplomacy and most of the countries that adjoined to the NAM turned out to be very close. The views of the international communist movement and most of the nonaligned countries on racism and Zionism in these decades were also fairly close. As noted in the foreign policy sections of the materials of the XXV and XXVI Congresses of the Soviet Communist Party, among the most important international goals should be considered "the complete elimination of all remnants of the system of national oppression... all hotbeds of colonialism and racism" (Materials of the XXV Congress of the CPSU, 1978, p. 26). Once again, it should be emphasized that Soviet diplomacy in the 1960s-1980s approached the problem of non-aligned countries in a differentiated manner. Thus, the general internationalism of Soviet policy was not abstract and de-ideologized. Particular attention was paid to countries whose governments pursued an anti-American direction in foreign and 
revolutionary-democratic policies in the domestic sphere, that is, the countries of "socialist orientation". Since such states often held leading positions in the NAM, this factor worked in favour of expanding the complex relationship between Moscow and the Movement and strengthening the USSR's prestige among the non-aligned countries. Another instrument of the Soviet Union's policy towards progressive or socialist-oriented countries was the treaties that Moscow concluded with these states. Only in the 1970s, the USSR concluded a series of similar agreements on friendship and cooperation with such non-aligned countries as India, Iraq, São Tomé and Príncipe, Angola, Mozambique, Afghanistan, Ethiopia, Vietnam, South Yemen, Syria. It can be stated with all certainty that it was precisely the states of "socialist orientation" in the 1960s-1980s that acted within the NAM as a key pillar of Soviet influence on the nonaligned countries. And above all, this concerned those socialist countries that were strategic allies to the Soviet Union (in particular, within the Council for Mutual Economic Assistance) - Cuba and Vietnam. Taking into account the fact that Cuba's chairmanship in the NAM coincided with another round of escalation of the Cold War (1979-1983), such an event could not but affect the climate of relations between the USSR and the NonAligned Movement member countries. In general, Soviet statesmen followed with particular interest and attention the preparation and course of those NAM conferences. In particular, from the official Moscow point of view, the Havana Conference (1979) showed that "the world socialist system countries and the states participating in the non-aligned movement face a number of common tasks related to countering the aggressive policy of imperialism, the final elimination of the remnants of colonialism, the restructuring of an unequal discriminatory system of international economic relations..." (Non-Aligned Movement, 1985, p. 380). At the same time, the Soviet leadership paid great attention to the chairmanship of the NAM countries, with the authorities of which the CPSU did not have strong ideological solidarity, but these countries at one time received independence and international recognition thanks to the principled position of the USSR and, in addition, the Soviet Union maintained friendly and respectful relations with these states (India, Zambia). In these cases, Soviet diplomacy has always also welcomed the chairmanship of such states within the framework of the NAM. For example, in the welcoming message of the Soviet authorities to the Movement Delhi Conference, it was noted that "in the Soviet Union, the efforts of the non-aligned movement in the struggle for peace and security of peoples, for ending the arms race and disarmament, for restructuring international economic relations on a just 
democratic basis, for full and comprehensive decolonisation have been and are being found." (Greetings from the Presidium of the Supreme Soviet and the Council of Ministers of the USSR .., 1983, p. 2).

\section{The Period of Détente}

In the conditions of detente in international relations, as well as the escalation of the international situation, the line on strengthening the strategic partnership of the USSR with the non-aligned countries was explained by the firmly anti-war position, which the Movement defended on the world stage. The Soviet press regularly emphasized that the Movement is one of the active fighters for strengthening relations of peaceful coexistence and easing tensions on Earth. At the same time, they also emphasized that within the framework of the world community, in the UN, the positions of the Soviet Union and the NAM countries on the most important issues of world politics significantly coincide. So, in the late 1970s-early 1980s "the Soviet Union and other socialist countries voted against the US proposals in $80.8 \%$ of cases, the bulk of developing countries - in 87.8\% of cases." (Non-Aligned Movement, 1985, p. 395). As you know, during the period when Leonid Brezhnev (19641982) was the General Secretary of the CPSU Central Committee, the Soviet state came up with a series of proposals aimed at strengthening international security, eliminating weapons of mass destruction and qualitatively reducing conventional weapons. Since Soviet peace initiatives were generally global in nature, these ideas had a direct bearing on the developing world as well; and so they met positively in the Non-Aligned Movement. In addition, the Soviet concept of security in the political field put in the first place "unconditional respect in international practice for the right of each people to sovereignly choose the paths and forms of their development." (World Socialism and the Non-Aligned Movement, 1988, p. 60). Even if this thesis was not always fully implemented in practice (Afghanistan, the countries of the Eastern bloc), doctrinally the NAM was in solidarity with this approach. Within the framework of the UN and at other international forums, Soviet diplomats have consistently defended the rights of the peoples and countries of the developing world - in the face of the West's neocolonial policy. For its part, the Soviet Union supported all the key ideas of the NAM aimed at abandoning nuclear weapons and other types of weapons of mass destruction and for creating nuclear-free zones. "The idea of creating nuclearweapon-free zones in the world was first put forward by the Soviet Union in 1956 when the Soviet government, in order to change the military danger in Central Europe, proposed to ban the deployment of nuclear weapons on its 
territory. The Soviet Union has always been a resolute supporter of the creation of nuclear-free zones in other regions as well - in the Mediterranean and the Middle East, on the African continent as in Latin America." (NonAligned Movement in the Modern World, 1985, p. 208). It should be noted that during the "symbolic" votes at the UN General Assembly on issues related to the creation of such nuclear-free zones, the Soviet Union always clearly and definitely supported the majority of the non-aligned countries' point of view. Another fact that confirms the similarity of the NAM and the USSR approaches stems from the fact that on key aspects of world politics and, in particular, on the most serious conflicts of the Cold War in the Third World, the NAM positions were quite friendly to Soviet policy at that time (Kostyuk, 2018, p. 160). Indeed, if we compare the positions that the NonAligned Movement defended during the Vietnam War, the struggle of the Portuguese colonies in Africa for independence, the conflicts of the racist regime of South Africa with neighbouring liberated countries, regarding the Arab-Israeli confrontation, internal political conflicts in Central America, individual interventions by the United States, it can be concluded that the views of Moscow and the NAM as a whole were very close to each other. For the Soviet Union, this was all-important because dozens of the NAM member countries, many of which did not adhere to a "revolutionary-democratic" worldview, in key UN's votes made a choice in favour of the position defended by the USSR. Moreover, the NAM's "systemic" rejection of neocolonialism, racism and Zionism made the Movement an objective "ideological" ally of Moscow in determining its position in relation to specific "hot spots" of the Cold War. However, it would be historically incorrect to talk about the complete approaches coincidence of the Soviet diplomacy and non-aligned countries on various conflicts or disputable situations, especially during the escalation in the late 1970s - first half of the 1980s. So, in these years, consistently advocating the rejection of a foreign military presence, most of the Movement member countries supported the idea of withdrawing the Soviet military contingent from Mongolia. Since Moscow actively supported the actions of the Vietnamese side to overthrow the Khmer Rouge regime in Cambodia, the NAM member countries, for the most part, demanded an end to the Vietnamese military presence and the formation of a coalition inter-party government in Cambodia (Kampuchea). Taking into account the fact that in Asia it was the Socialist Republic of Vietnam that acted as the main and strategic ally of the USSR, the "Cambodian issue" turned out to be quite painful and unpleasant for Moscow. However, the Afghan issue, which directly concerned the Soviet Union, became the most acute and difficult for Soviet diplomacy in its relations with the NAM during 
the entire Cold War period. An analysis of decision-making during the 1980s on the Afghan issue at the UN indicates that most NAM member states were inclined to condemn the USSR in the Afghan conflict (Kostyuk, 2018, p. 161). In particular, most of the Asian and African Muslim countries unambiguously demanded the early and urgent Soviet armed contingent withdrawal from the Afghan territory. "In general, the Non-Aligned Movement on the issue of the Afghan conflict did not agree with the USSR's position... but with the UN's position taken with regard to the situation in the country." (Kostyuk, Rabush, 2020, p. 118). The "Afghan factor" in the early 1980s played a role in the process of weakening Moscow's foreign policy prestige among the non-aligned states, and only a change in the course in the Afghan direction under Mikhail Gorbachev changed the situation for the better for the Soviet Union. Considering the Soviet leadership approach to the Non-Aligned Movement and its activities, we must always remember that in an era of relative bipolarity in international relations, the USSR did not act only as a powerful military power, but it headed the "world socialist system", the Warsaw Pact Organisation and the Council for Mutual Economic Assistance. The Communist Party of the Soviet Union, in turn, played a primary and priority role in the international communist movement. The internationalist and communist foreign policy pursued by the Soviet Union in the global arena, respectively, predetermined the approaches of Moscow-oriented international associations towards the NAM. And the leading role in defining these approaches belonged, of course, to Soviet diplomacy. The representatives of the socialist countries in their totality stated: "The Non-Aligned Movement draws inspiration from the fact that its ideals find understanding and support from world socialism, all world progressive forces. The USSR and other socialist countries have always attached great importance to the Non-aligned Movement, considering it one of the important factors in modern international relations." (Non-Aligned Movement, 1985, p. 11). We can immediately add that in the Declaration of the state's heads of the Warsaw Pact Organisation (1978) it was noted that the socialist countries "consider the Non-aligned Movement as a positive factor in international politics, noting its increased role in the world arena." (Non-Aligned Movement, 1985, p. 11). As already noted, the "world socialist system" was represented in the Movement by Cuba and Vietnam, which enjoyed considerable authority within the NAM. Later, the Democratic People's Republic of Korea was admitted to the Movement, which also corresponded to Moscow's international interests. Laos that was ruled by the Marxist-Leninist party also took part in the Movement. Of course, the fact of the participation of Cuba, Vietnam, Laos and North Korea in the NAM did 
not mean that in those decades they were in fact non-aligned nations: in the framework of the Cold War, all these countries clearly belonged to the "socialist community" and were the USSR's loyal allies. Since the Khrushchev period, the Socialist Federal Republic of Yugoslavia was also viewed by Soviet leaders as a socialist country. So the factor of Yugoslavia's active participation in the NAM has been seen very positively by the Soviet side. Moscow's Eastern European allies also welcomed the activities of the Movement in every possible way. Thus, at the meeting of the Warsaw Pact countries in Bucharest (1976), it was stated that "the Fifth Conference of the Non-Aligned Countries State and Government Heads once again demonstrated their positive role in international relations." (Warsaw Pact Organisation, 1980, p. 206). Such countries as the German Democratic Republic, Hungary, and Romania willingly built their own relations with the NAM, without questioning, however, the leading foreign policy positions of the Soviet Union. As a rule, at the summits of both the Warsaw Pact Organisation and the Council for Mutual Economic Assistance in the 1970s and 1980s documents, which emphasized the positive significance of the NAM for the cause of peace and security and for the current world politics in general, were regularly adopted. At the same time, both of these USSRled international organisations invariably maintained that their strategic course towards the non-aligned countries was consistent with the principles of proletarian internationalism, which favourably distinguishes the approach of "real socialism" from capitalist neocolonialism. In particular, the statement of the Political Consultative Committee of the Warsaw Pact Organisation (1978) declared: "In no parts of the world do socialist countries seek privileges for themselves, do not covet bases, do not hunt for concessions. While in principle opposed to the imperialist policy of creating spheres of influence, they themselves never participate in the struggle for such spheres." (Warsaw Pact Organisation, 1980, p. 236). At the suggestion of Moscow, all the countries participating in the Warsaw Pact proceeded from the thesis of the need to strengthen the versatile relations of the "world socialist system" and the postcolonial countries on the basis of common anti-imperialist principles and commitment to the international relations democratization. For example, such slogans have been consistently used by countries such as Hungary and Romania. But here it is important to remember that, after all, they originally came from Moscow. From the communist countries' point of view, "the closer the relations of individual participants in the movement with the socialist community, the more opportunities they have to resist imperialist pressure, ensure their independent development, and overcome economic dependence." (The Non-Aligned Movement in the Modern World, p. 7). 
Since within the UN Moscow's Eastern European allies voted in solidarity with the Soviet Union every time, a similar vote on most world politics issues with most of the NAM member states also worked to strengthen mutual relations along the "socialist countries - Non-Aligned Movement" line. Together with the USSR, the allied countries welcomed the anti-war dimension of the NAM's activities, believing that the Movement is making a significant contribution to the cause of detente and the international situation "unfreezing". As noted by the Warsaw Pact countries, "a growing contribution to the elimination, prevention of crisis situations is being made by the Non-Aligned Movement, whose practical steps in this direction deserve recognition and support from all states." (Political Declaration of the States Parties to the Warsaw Pact Organisation, 1983, p. 5). To some extent, it is legitimate to talk about the "developed socialism" international associations states "division of functions" in relation to the NAM. So, if the Warsaw Pact Organisation focused more attention on the positions similarities with non-aligned countries in relation to world politics pressing problems, international crises, global security, disarmament, the need to renounce weapons of mass destruction, then the Council for Mutual Economic Assistance, in turn, paid more attention to the proximity of positions with non-aligned countries on the theme of the struggle for a new just economic order. In this regard, it is useful to cite an excerpt from the 1984 Declaration of the Council for Mutual Economic Assistance Member States: "Noting with satisfaction the increased importance of the Non-Aligned Movement as a powerful factor in the struggle against imperialism, colonialism and neocolonialism - the forces of war and aggression, the participants in the Meeting express their solidarity with the decisions and message of the Seventh Conference of Non-Aligned Countries State and Government Heads in Delhi, aimed at solving the fundamental problems of our time: the struggle to consolidate world peace, peaceful coexistence, disarmament, national independence, ensuring the economic and social development of each country." (Declaration of the CMEA member countries .., 1984, p. five).

\section{Realistic perception of the relations between the Soviet Union and the Non-Aligned Movement}

Today one could say that the perception in the Soviet Union of the NonAligned Movement's strategy and activities had a clear "romantic" connotation. However, we must take into account the real historical past events and the fact that the Soviet leaders proceeded not only from their own 
ideological predilections. In particular, already at the founding conference of the NAM in Belgrade in 1961, it was emphasized: "The non-aligned countries represented at the conference do not want to create a new bloc and sincerely want to work with other governments committed to promoting trust and peace around the world." (Two Decades of Non-Alignment, 1983, p. 6). Undoubtedly, this message coming from the young Movement was heard and favourably received by the leaders of the USSR and the CPSU. Moscow attentively followed how the NAM summits positively react to Soviet initiatives on nuclear and conventional disarmament, peaceful conflict settlement, how they assess the Soviet position on overcoming the remnants of the colonial system. In the 1970s and 1980s, the Soviet Union actively promoted the idea of fighting for a new, fairer international order. This topic played an important role in the "menu" of Moscow's relations with the countries of "socialist orientation", Socialist International, and neutral states. But for relations with the NAM, this issue was very relevant. It should be pointed out here that the bulk of the Movement members, and above all the NAM "natural leaders", also in principle shared the thesis about the need to move towards a more just world. Countries such as Yugoslavia, Cuba, and India openly supported the very principle of a radical international political and economic relations restructuring. Within the UN's framework, socialist countries and non-aligned states regularly voted for resolutions supporting the transition to a just new world economic order. In turn, all these points were drawn to the attention of political leaders and the media of the US and their Western European allies, who often saw the NAM as a kind of Moscow's "tail" and believed that the Movement played the role of a Soviet hidden ally in world politics. However, the Movement's leaders themselves rejected this interpretation. For example, Indian Prime Minister Rajiv Gandhi reasoned: "We do not attach importance to how many times the Soviet Union, the US or any other state votes with us. We vote in the UN on the basis of certain principles that we consider to be correct and justified." (World Socialism and the Non-Aligned Movement, 1988, p. 76). Thus, R. Gandhi, like other left and centre-left Movement leaders, made it clear that nonalignment, in fact, does not mean "sterile" neutrality and total equidistance from the key poles of international relations. Even more vividly and directly positive role of "the USSR factor" was emphasized by those NAM leaders whose countries were clearly involved in the world socialist system. As the chairman of the Cuba State Council, Fidel Castro noted, "if there were no the Soviet Union, it would have been impossible even to imagine the measure of independence enjoyed by small states, or the peoples' successful struggle to regain control of natural resources, or the fact that their voice would sound 
significant in a concert of nations." (Starushenko, Bochkarev, 1983, p. 30). The leaders of Vietnam and North Korea made similar statements about the Soviet Union. As we have already noted, the relations of the USSR with developing and non-aligned countries were of a complex nature. Of course, much of Moscow's attention was paid to political and ideological similarities, foreign policy closeness, cooperation in the military sphere, as well as humanitarian and cultural aspects. But even if for the Soviet Union and its allies the economic dimension of interstate relations in the 1960s-1980s was not the most important, yet this aspect of the relationship cannot be completely ignored. It should be borne in mind here that "the share of developing countries in the foreign trade of the CMEA members reached $12 \%$. The total share of loans provided to them by the CMEA states for the economic and social development purposes has more than doubled in the 70s." (Non-Aligned Movement, 1985, p. 389). The volume of Soviet loans to non-aligned countries also grew. In essence, the economic and trade relations of the USSR with the countries participating in the NAM, indeed, were of equal and mutually beneficial nature; they were realized at the same time outside the capitalist logic of profit. Concluding long-term interstate economic and trade agreements with non-aligned countries, the Soviet Union especially emphasized that these agreements are directed against any form of discrimination and exploitation. The Soviet Union actively assisted developing countries in laying the foundations for heavy industry, building large industrial facilities, developing transport and infrastructure, and creating hydroelectric power plants. Certainly, the closest trade and economic relations were built with those countries whose governments proclaimed their socialist orientation. In this case, Soviet specialists and experts provided these states with very impressive, often gratuitous assistance, however, in the final analysis, the economic system of such states was built according to Soviet recipes - with all the pros and cons of such "copying". At the same time, the USSR actively maintained trade and economic relations with those non-aligned countries that remained in the "capitalist paradigm", but at the same time tried to maintain partner relations with Moscow in foreign policy. Here the "red line" was the attitude of the non-aligned states to the democratizing international economic system idea, for which the Soviet Union and the world socialist system countries did not stop advocating during the Cold War era. It was especially appreciated in Moscow that at the "organisational" level, the NAM welcomed this idea and considered it necessary and useful. In one of the Soviet Council of Ministers' statements in the mid-1970s was noted: "The Soviet Union, guided by its unchanging course to consolidate peace, to improve the entire system of international 
economic relations, consistently advocates their restructuring on a democratic and just basis. At the same time, he proceeds from the fact that the fundamental interests of the socialist countries and developing states in this area basically coincide." (Statement of the Soviet government "On the restructuring of international economic relations", 1976, p. 1). Thus, we see that in the socio-economic dimension the ideological component in relations along the USSR-NAM line was of no small importance. Of course, the topic of the struggle for a new international economic order was the most popular among the leftist regimes of non-aligned states although it was not limited to them alone. It is known that in the 1970s and 1980s, the Soviet Union "promoted" the essential principles of this order not only among the countries of "socialist orientation". From the Soviet leaders' and party ideologists' point of view, it was necessary to prioritize those moments that brought Moscow's and the non-aligned states' opinions closer to the qualitative restructuring of international economic relations. The following are the fundamental provisions that were close - for the USSR and the nonaligned countries: "The thesis of the developing countries unequal position in the world order as a colonial past and the continuing neocolonial exploitation consequence; ascertaining the growing gap in the level of developing and industrialised countries economies; emphasis on curbing the financial exploitation of developing countries, capital outflow; the provision on the need to reduce the cost of weapons in the economic development interests." (World Socialism and the Non-Aligned Movement, p. 85). Mikhail Gorbachev's accession to the CPSU Central Committee General Secretary post in 1985, on the one hand, contributed to the international tension relaxation and, on the other, to an even greater extent focused the official Moscow's attention on the Non-Aligned Movement activities, which continued to be perceived as an important and strategic partner of the Soviet Union. Justifying the principles of new political thinking, M. Gorbachev pointed out that the NAM "contributes to the construction of new-type international relations - with all the nuances and peculiarities of it... NonAligned Movement realizes the liberated people desire for equal cooperation, recognition by others exclusive rights and interests, to the exclusion of manifestations and diktat from international life claims to hegemony. The Soviet Union understands the Non-Aligned Movement's goals and agrees with them." (Gorbachev, 1988, p. 186). In Soviet and Russian scientific literature in the late 1980s-early 1990s, emphasis was placed on the need for de-ideologization of international relations; after 1987, Moscow markedly weakened the scale of political and military support for its allies in Asia, Africa and Latin America. Belonging to a communist or revolutionary- 
democratic ideology is gradually ceasing to be the fundamental link connecting the USSR and the "third world" countries. At the same time, the NAM is viewed by Russian experts as "a new type of interstate cooperation, coordination and consolidation of different policy courses, development of a collective platform on many major international problems." (Utegenova, 1991, p. 19). Under the influence of state foreign policy and international situation changes, we find a revision of the NAM and its activities' specific perception in the late Soviet academic literature. At the same time, the attitude towards the very concept of non-alignment was changing - in line with the approach of de-ideologization, a break with the class component. As the researcher D. Utegenova points out in her work "The UN and the Non-Aligned Movement" from 1991, "the concept of non-alignment opens the way to the restructuring of international relations on the basis of political equality and economic justice not through confrontation but through the international cooperation development and strengthening before all on the principles of multilateralism, active use of the UN system." (Utegenova, 1991, pp. 108-109). In the second half of the 1980s, the Soviet Union actively promoted the disarmament and renunciation of lethal weapons slogans, while at the same time advocating the military-political bloc's renunciation in various parts of the world. These thoughts were quite consonant with those advocated by the NAM member countries. We also note that the specific practical actions of Gorbachev leadership (the Soviet military contingent withdrawal from Afghanistan, the Soviet unit's withdrawal from Mongolia, encouraging Vietnam to withdraw its contingent from Cambodia, direct or indirect assistance from Moscow in resolving the long-term conflicts in Asia, Africa and Latin America) were also welcomed at the Non-Aligned Movement level. The Soviet Union, in turn, during Mikhail Gorbachev's leadership, solidified with the "zones of peace" concepts, which were promoted by the non-aligned countries. In particular, this applied to the Mediterranean Sea and the Indian Ocean areas. The USSR's position regarding the transformation of the Indian Ocean into a zone of peace was "based on the comprehensive international security system concept" (Utegenova, 1991, p. 89). Note that in 1986 the Non-Aligned Movement addressed Mikhail Gorbachev and U.S. President Ronald Reagan with a Disarmament Appeal, which called on both superpowers to take concrete steps to prevent the outbreak of nuclear war. "The USSR's response showed full solidarity with the Non-Aligned Movement on this issue." (World Socialism and the Non-Aligned Movement, 1988, p. 21). It can also be noted that in 1986 the Soviet Union and India, following the summit, adopted the Delhi Declaration on the principles of a nuclear-weapon-free and non-violent 
world; this document was actively supported at the NAM level as well. As M. Gorbachev noted, "our philosophical and political approaches to building a nuclear-free, non-violent world are aligned with the approaches not only of India, but also of the billions of people represented by the Non-Aligned Movement." (World Socialism and the Non-Aligned Movement, 1988, p. 32).

\section{Changes towards the NAM in the post-Soviet era}

The USSR's dramatic collapse led to powerful consequences and, in particular, to an objective decrease in the geopolitical influence of its main legal successor, the Russian Federation. We can say with all confidence that during the "Yeltsin" period of Russian history, the new Russian leadership almost completely ignored the existence of the NAM, while the interstate relations of the Russian Federation with the leading non-aligned countries in political or economic areas have been reduced to zero. In this regard, it is logical that the Russian international prestige among the majority of nonaligned states has sharply decreased compared to the Soviet era. It is hardly a coincidence that in all versions of the Russian Foreign Policy Concept for the entire post-Soviet period (including its latest edition of 2016) nothing is said about the NAM. Contrast with the period of the 1960s-1980s is more than obvious. For Russia in the 21st century, non-aligned and developing countries in their integrity are not a geopolitical priority. However, the Kremlin's course towards maintaining multipolarity in the system of international relations and the confrontation with the "collective West", which has intensified especially since 2014, objectively led to the intensification of actions by Russian diplomacy in relation to the NonAligned Movement. This became a reality in the late 2010s also because in this decade the Movement was headed by countries (Egypt, Iran, Venezuela, Azerbaijan) with which Moscow maintains friendly foreign policy relations. Let us also remind that within BRICS Russia closely interacts with such extremely influential countries in the NAM as India and the Republic of South Africa. Taking into account the fact that in the world arena the NAM continues to advocate multilateralism, strengthening the role of the $\mathrm{UN}$, and democratizing international relations, it is not surprising that the Russian leaders see the Movement as an authoritative international association that should be viewed as a partner of the Russian Federation and as a force or the oppositional perspective of the complete "collective West" and its institutions' domination in modern international relations. This point of view is all the more justified since today a number of states of the post-Soviet space - Azerbaijan, Belarus, Turkmenistan, Uzbekistan - are included in the 
ranks of the Movement. With all these countries, Moscow is determined to build multi-directional relations. Even if today the role and place of the NAM in world politics do not seem as convincing and obvious as it was in the 1960s-1980s, for the Russian state the "Non-Aligned Movement factor" in the system of international relations seems important and promising. It is in this vein that the Russian Federation's request for observer status in the NAM, voiced in October 2020, should be viewed (Russia has requested observer status in the Non-Aligned Movement, 2020). The latest NAM conferences were invariably attended by official delegations representing the Russian Federation, which also confirms the significance and importance of the Movement for the Russian current foreign policy. So, at the Eighteenth meeting of the NAM Head of State and Government in Baku (2019), Deputy Foreign Minister of the Russian Federation Sergei Vershinin said: "We are ready to further build up cooperation with the Movement in the interests of strengthening international stability, for the benefit of our countries and peoples, the entire world community." [Speech by the Deputy Minister of Foreign Affairs of the Russian Federation S.V. Vershinin, 2019]. The NAM, from Moscow's point of view, is the most active in promoting the principles of multipolarity in modern international relations. The theme of Moscow's approaches and of the countries which are part of the NAM to promote a multipolar system is reflected in the Russian president's position. In his message to the Baku NAM conference, Vladimir Putin noted that "Russia consistently supports the efforts of the Non-Aligned Movement aimed at building a multipolar system of world order, at developing equal international dialogue and cooperation based on generally recognized legal norms and taking into account the legitimate interests of partners." (Speech by Deputy Minister of Foreign Affairs of the Russian Federation S.V. Vershinin .., 2019). It is obvious that in today's contradictory and difficult international conditions for the Russian Federation, the Non-Aligned Movement is indeed capable of becoming a serious foreign policy partner for Moscow.

\section{Conclusions}

Summing up the general results of this chapter, we can state that in the initial period of the NAM existence, it was perceived by the Soviet leadership as a positive factor in the international relations system. Moscow immediately saw NAM as an ally in the general anti-colonial and antiimperialist struggle, in the confrontation on the international arena of racism and Zionism, appreciated the anti-militarist potential of the Movement. At 
the same time, the "most favoured nation" regime on the part of the USSR extended to those non-aligned countries that developed in the spirit of socialist orientation. On the most topical issues of world politics and military-political conflicts, the positions of the Soviet Union and the NAM coincided or turned out to be very close. At the same time, disagreements over the situation around Afghanistan turned into a serious problem in relations between the USSR and the NAM. In the framework of the discussions at the UN General Assembly on the world politics key problems, in the overwhelming majority of cases, the bulk of the countries participating in the NAM voted with the Soviet Union. Moscow also defined and coordinated the overall strategy of relations with the NAM on the part of the Warsaw Pact Organisation and the Council for Mutual Economic Assistance. During the period of detente and in the 1980s great importance on the part of Soviet diplomacy was attached to the interaction with the NAM in the struggle for a new, more just and democratic economic order. The "Gorbachev" period became, in fact, the apogee in terms of the Moscow's and the Movement's approaches convergence. After the USSR's collapse, interest and attention to the activities and the factor of the NAM in the international relations system dropped dramatically. In recent years, under the influence of geopolitical motives, the Russian Federation has noticeably intensified its relations with the Movement, as evidenced by the request for observer status in the NAM in 2020.

\section{References}

Движение неприсоединения (1979). Москва, Издательство «Наука» [Non-Aligned Movement (1979). Moscow, Nauka Publishing House].

Движение неприсоединения (1985). Москва, Издательство «Наука» [Non-Aligned Movement (1985) Moscow, Nauka Publishing House].

Движение неприсоединения в современном мире (1985). Москва, Международные отношения [Non-Aligned Movement in the Modern World (1985). Moscow, International relations].

Декларация стран-членов СЭВ «Сохранение мира и международное экономическое сотрудничество» (1984, 16 июня). Правда, р. 5-6. [Declaration of the CMEA member countries "Preservation of Peace and International Economic Cooperation" (1984, June 16). True, p. 5-6].

Дмитриева, О. А. (1990). Движение неприсоединения и региональные конфликты. Москва, ГПСИ ИМЭМО АН СССР [Dmitrieva, О. А. 
(1990). Non-Aligned Movement and Regional Conflicts. Moscow, SPSI IMEMO USSR Academy of Sciences].

Заявление Советского правительства «О перестройке международных экономических отношений» (1976, 5 октября). Праљда, С. 1. [Statement of the Soviet government "On the restructuring of international economic relations" (1976, October 5). True, p. 1].

Горбачёв, М. С. (1988) Перестройка и новое мышиение для нашей страны и всего мира. Москва, Издательство политической литературы [Gorbachev, M.S. (1988) Perestroika and new thinking for our country and the whole world. Moscow, Publishing house of political literature].

Jackson, R. L. (1983). The Non-Aligned, the USA and superpowers. New York, Praeger.

Костюк, Р. В. (2018). Диалектическая биполярность: к вопросу о роли Движения неприсоединения в эпоху холодной войны, Вестник Санкт-Петербургского государственного университета технологии и дизайна, серия 2, №3, 156-163 с. [Kostyuk, R.V. (2018). Dialectical Bipolarity: On the Role of the Non-Aligned Movement in the Cold War, Bulletin of St. Petersburg State University of Technology and Design, series 2, no. 3, pp. 156-163].

Костюк, Р. В., Рабуш, Т. В. (2020). Позиция Движения неприсоединения в афганском вооружённом конфликте в 1980-е гг., Вестник СанктПетербургского государственного университета технологии и дизайна, серия 2, №2, 117-123 c. [Kostyuk, R.V., Rabush, T.V. (2020). The position of the Non-Aligned Movement in the Afghan Armed Conflict in the 1980s, Bulletin of the St. Petersburg State University of Technology and Design, series 2, no. 2, pp. 117-123].

Материалы XXV съезда КПСС (1978). Москва, Политиздат [Materials of the XXV Congress of the CPSU (1978). Moscow, Politizdat].

Материалы XXVI съезда КПСС (1981). Москва, Политиздат [Materials of the XXVI Congress of the CPSU (1981). Moscow, Politizdat].

Мировой социализм и Движение неприсоединения (1988). Москва, Международные отношения [World Socialism and the Non-Aligned Movement (1988). Moscow, International relations].

Организация варшавского договора: Документы и материалы, 19551980 (1980). Москва, Политиздат [Organization of the Warsaw Treaty: Documents and Materials, 1955-1980 (1980). Moscow, Politizdat].

Политическая декларация государств-участников Организации Варшавского договора (1983, 7 января). Правда, С. 5. [Political 
Declaration of the States Parties to the Warsaw Pact Organization (1983, January 7). True, p. 5].

Приветственное послание Президиума Верховного Совета и Совета Министров СССР Делийской конференции глав государств и правительств неприсоединившихся стран (1983, 7 марта). Праљда, С. 2. [Greetings from the Presidium of the Supreme Soviet and the Council of Ministers of the USSR to the Delhi Conference of the Heads of State and Government of the Non-Aligned Countries (1983, March 7). True, p. 2].

Россия запросила статус наблюдателя в Движении неприсоединения (2020) retrieved from http://ria.ru/20201022/neprisoedinenie1580961121.html (Accessed 29 January 2021) [Russia has requested observer status in the Non-Aligned Movement (2020)].

Старушенко, Г. Б., Бочкарёв, Ю. А. (1983) Сотрудничество СССР с освободившимися странами. Москва, Международные отношения [Starushenko, G.B., Bochkarev, Yu. A. (1983) Cooperation of the USSR with the liberated countries. Moscow, International relations].

Two Decades of Non-Alignment. Documents of the Gathering of the Nonaligned Countries, 1961-1982. (1983) New Delhi, Ministry of External Affairs.

Утегенова Д. К. (1991). ООН и Движение неприсоединения. Москва, Наука, Главная редакция восточной литературы [Utegenova D.K. (1991). UN and Non-Aligned Movement. Moscow, Science, Main edition of oriental literature].

Выступление заместителя Министра иностранных дел Российской Федерации С. В. Вершинина на 18-й Встрече глав государств и правительств Движения неприсоединения, Баку, 25-26 октября 2019 года (2019), retrieved from http://mid.ru/press_service/deputy_ ministers_speeches/-/asset_publisher/O3publba0cjv/content/ id/3867353 (Accessed 28 January 2021) [Speech by Deputy Minister of Foreign Affairs of the Russian Federation S.V. Vershinin at the 18th Meeting of Heads of State and Government of the Non-Aligned Movement, Baku, October 25-26, 2019 (2019)]. 